\title{
Editorial
}

\section{The evolving message of the trade mark}

It is an honour for me to be a practitioner of intellectual property, but then that perspective might be expected from someone who thinks that intellectual property law is the honours college of the legal university; the place where the best and most exciting thinking goes on.

That may seem a naive view to posit in so sophisticated a journal as The Journal of Brand Management. Nonetheless, I am boldly willing to do so, suspecting that at least a few of the readers of this fine journal share my enthusiasm. I would wager that more than a few of our fellow readers amuse themselves while standing in long checkout lines, by reading and, indeed, even studying, the packaging of the products available in the stores.

While I expect that shoppers for at least the last two millennia have also amused themselves likewise, those shoppers before us did not have the abundance or variety of trade mark uses to study that we have today. In this Editorial, I would like to briefly comment upon a few of the changing areas of trade mark protection.

One of the principal changes that has occurred in trade mark law is the expanded nature of what a trade mark signifies and symbolises. Two millennia ago, and even as recently as 50 years ago, a trade mark was a symbolic representation of the quality or predictable standard of expectation that a consumer could reliably find in the actual product. For instance, a consumer bought a Cadbury chocolate bar because only Cadbury chocolate bars had a particular texture, melting point or flavour. A shopper bought Quaker Oats because he wanted the assur- ance which the mark gave: that is, the grains contained inside the package were of a pure, unadulterated standard. The fact that a consumer had the money to buy a specific branded product did not usually place that consumer in any particular social class, strata of society, or lifestyle category.

The limited scope of a trade mark as the standard-bearer of the precise quality of a product has evolved and expanded in nature. Readers over the age of 30 will best understand this change when they compare what it meant in their childhood with what it means today, to wear a garment emblazoned with a non-garment trade mark. In most households of the 1950s, if a youngster donned a T-shirt bearing a large depiction of the Cadbury mark, it usually elicited a comment from a family elder, who would heckle the youngster with questions of whether the Cadbury company was paying the youngster to be a human billboard. The general consensus was that if you agreed to allow a company to broadcast your endorsement of its mark, you should be compensated.

In sharp contrast, people young and old now expend vast amounts of personal time and money to acquire, even collect, garments which bear conspicuous trade marks. For instance, people with enough affluence and leisure time to exercise show off that affluence by wearing T-shirts bearing exercise product marks such as Stairmaster, Capezio, Life Cycle, Tunturi and others. Fashion-conscious gentlemen growing in years and size, who require denim trousers to fit their aging figures, do not merely slouch to the largersized trouser section. Instead, they shop long and hard to find Levi 501 jeans, because such 
a mark conveys that although the consumer is aging, he remains vibrant, fashionable and part of the growing, not receding, edge of society.

Today, trade marks and service marks of social events also adorn garments, which in earlier times people would only wear if they were directly or indirectly paid by service or honour. For instance, ten years ago a T-shirt displaying the name of a local theatre performance would have only been seen on theatre workers, usually to help the theatre's security sort out the attendees from the working staff. Nowadays, T-shirts bearing the name of a theatre or theatre performance title are regularly sold and eagerly purchased by attendees. In fact, a loose ethics concerning ownership of these special T-shirts has evolved. For example, a person might be scorned if found wearing a T-shirt describing a theatre performance or sporting event that he did not, in fact, attend or in which he did not compete. The following conversation regularly occurs between the wearer of a T-shirt bearing the large conspicuous phrase, 'San Francisco Opera, La Bohème, 1993'.

'Oh, you are a subscriber to the San Francisco Opera; what a wonderful organisation; what a terrific stage set!'

The wearer might sheepishly respond with the words, 'I didn't go; my girlfriend gave me the shirt.'

The observer will usually think and occasionally respond, 'So you aren't really entitled to wear that T-shirt, because you didn't earn the right. You didn't attend'.

That same conversation plays itself out again and again when the T-shirt bears the New York Marathon logo, or the trade mark of any other well-known sporting or cultural event.

Bottled water manufacturers were among the leaders to usher in this change in perception of trade marks by the consuming public. A person who drank bottled water contained in small, club-shaped, green bot- tles did not always choose Perrier mineral water because he wanted the standard of quality of mineral water found within those small, club-shaped, green bottles. Instead, the consumer would buy the product because the packaging signalled to the observing public that the consumer subscribed to a particular lifestyle. In this instance, the signal was very consistent, and was the consumer's means of saying: 'I am affluent enough to buy what I could get for free - a glass of water; and I have a lifestyle in which I acquire the best, the purest, the most expensive in the spectrum of purchasing opportunities'. Thus, it was the packaging, the container of the product, which became the symbol sought to convey a larger message than that of product quality. The lifestyle became the message; the product was just a tertiary component of that message.

The United States has witnessed the expansion of trade mark usage in the unlikely arena of agriculture. Two millennia ago, it would have been laughable to think of fruit or vegetables labelled with trade marks.

Two decades ago, it was regarded as a novelty to see bananas individually carrying the Chiquita mark, or lemons and oranges individually bearing the Sunkist mark. Now such marks are common, and they are a signal to consumers, that a well-organised farm cooperative is making a concerted effort to carve out a market niche. Now we think nothing of seeing, and even asking grocers, for trade marked product names, such as Gala New Zealand apples, Cara Mia marinated artichokes, or Haas avocados.

With the increasing acknowledgment that tourism is among the most viable and healthy parts of the US economy, trade marks and service marks are expanding into the burgeoning field of 'agri-tourism'. Today, in agri-tourism, there are many examples of fabulous creativity; one example particularly stands out and serves well to illustrate the point. A family-owned fruit 
farm in the midwestern United States uses the mark Tree-Mendus to market, not just its fresh fruit, but the opportunity for city folk to become and remain more intimate with the farming cycle and seasons. As a subscriber or customer of Tree-Mendus services, one can rent a specific apple or peach tree; one can camp under it and visit it during any of the four seasons. Also, it is possible to call ahead on the 'ripe and ready' phone line to ascertain what is being harvested and what activities are scheduled for any particular weekend. The Teichman family who offer Tree-Mendus services, has created a living and highly accessible community for city folk who have lost touch with the agricultural cycle and want to re-establish and continue contact with that cycle. The trade mark, Tree-Mendus, serves, not so much as a source designator, but more as a lifestyle indicator. As a sub- scriber to Tree-Mendus services, one is informing the observing public of the way in which one has chosen to spend the resources of time and money.

It has long been said that copyright law is blown by the winds of technology. After reading this Editorial, perhaps you will join me in concluding that deliberate and proactive brand management, that is, trade mark and service mark management, is becoming a harbinger of altering cultural values, evolving personal identities, and changes in both conscious and unconscious forms of communication. In the past, the message of the trade mark was solely connected to the product; increasingly, the message of the trade mark is relevant to both lifestyle and product. 